\title{
Characterization of Esterases of Tamarindus indica Seeds
}

\author{
S. Kantharaju, K. R. Siddalinga Murthy \\ Department of Biochemistry, Central College Campus, Bangalore University, Bangalore, Karnataka, India \\ Email: kantharaj2553@gmail.com, krsmurthy2001@yahoo.com
}

Received February 2014

\begin{abstract}
Germinating seeds of Tamarindus indica synthesizes various enzymes which are required for the degradation of seed reserves such as xyloglucans, fatty acid esters and proteins. Among these, esterases, belonging to a group of hydrolytic enzymes catalyze the hydrolysis of various types of esters. They play an important role in cell expansion as well as detoxification of xenobiotics and many agrochemicals and insecticides. The esterases are extracted from the germinating tamarind seeds using $50 \mathrm{mM}$ phosphate buffer, $\mathrm{pH}$ 7. The $\mathrm{Km}$ with $\alpha$-naphthyl acetate as the substrate is $19.23 \mu \mathrm{M}$ and the enzymes are optimally active at pH 7.0 to 7.5 and are stable between $\mathrm{pH} 5.0$ to 9.0. The optimum temperature of esterase activity of tamarind seed is between $37^{\circ} \mathrm{C}-50^{\circ} \mathrm{C}$ and is stable up to $40^{\circ} \mathrm{C}$. The activity declined by $30 \%$ at $60^{\circ} \mathrm{C}$ and about $90 \%$ at $70^{\circ} \mathrm{C}$. Highest esterase activity and specific activity are observed on the $21^{\text {st }}$ day of germination. The polyacrylamide gel electrophoresis (PAGE) indicated the presence of nine isozymes of esterases. Band numbers 1, 5 and 6 are the major esterolytic bands present throughout the germination period while band numbers $2 \& 3$ are minor bands present only during the latter period of the germination. Based on substrate and inhibitor specificity in conjunction with electrophoresis, the esterases 1 to 8 have been classified as carboxylesterases sensitive to organophosphate inhibitor (OP) and PCMB (p-chloromercuribenzoate) while esterase 9 is classified as carboxylesterase sensitive to $\mathrm{OP}$. These esterases are unaffected by carbamate inhibitor, eserine sulphate.
\end{abstract}

\section{Keywords}

Tamarindus indica, Germination, Esterase, $\alpha$-Naphthylacetate, p-Chloromercuribenzoate, Eserine Sulphate, Dichlorvos

\section{Introduction}

Esterases are an important group of hydrolytic enzymes, catalyzing the hydrolysis of various endogenous and exogenous short chain carboxyl esters. They are widely distributed in nature and occur in multiple molecular forms and exhibit broad substrate specificity [1]. Esterases play an important role in the metabolism and detoxification of agrochemicals. In particular, carboxylesterases play an important role in agrochemical efficacy and detoxification by interacting with two major classes of agrochemicals, organophospate (OP) insecticides and 
pyrethroids [2]-[4]. The variability in esterase levels and relative isozyme abundance contributes to the selective toxicity of ester-containing insecticides in a range of organisms, from fish to insects and mammals. In animals, $\mathrm{OP}$ and carbamate insecticides exhibit their toxicity by irreversibly inhibiting acetylcholinesterase causing the disruption of the nerve impulse transmission due to the buildup of the neurotransmitter acetylcholine. In plants, esterases acts as an insecticide sink and protect insect acetylcholinesterases from OP/carbamate mediated toxicity. The present investigation was carried out to study the variation in esterase activity during the germination of tamarind seeds and characterize the esterases.

\section{Materials and Method}

\subsection{Materials}

BSA, glycine, tris, phosphoric acid, hydrochloric acid, glycerol, methanol, acetic acid, bromophenol blue, acetic acid, sodium dihydrogen phosphate, disodium hydrogen phosphate, $\alpha$-naphthyl acetate, diazo blue B, Fast Blue $\mathrm{RR}$, acrylaminde, methylene bisacrylamide are of analytical grade obtained from Sisco Research Laboratories Pvt. Ltd., India.

The seeds of Tamarindus indica are collected using random sampling technique (RST) from local areas of Bangalore district, Karnataka State, India, during February to May. After dehulling the seeds, immature and damaged seeds are removed and the mature seeds washed under tap water, dried and stored under refrigeration in plastic containers until further use. From this bulk population sample, subsamples are obtained.

\subsection{Methods}

\subsubsection{Germination Studies}

Healthy Tamarind seeds (one hundred) are soaked in cold $50 \% \mathrm{H}_{2} \mathrm{SO}_{4}$ for 60 mins and then washed thoroughly with distilled water and dispensed into the soil (1:1 ratio of acid washed sand and cocco peat). The seeds are germinated and the endosperms are collected every alternate day starting from $1^{\text {st }}$ day till $25^{\text {th }}$ day.

\subsubsection{Extraction of Esterase}

A $10 \%$ extract of the endosperm (at an interval of every 24 hours during germination) are prepared in $0.05 \mathrm{M}$ phosphate buffer $\mathrm{pH} 7.0$, by blending in a mixer for 5 mins and centrifuged at 10,000 rpm for 15 mins at $4^{\circ} \mathrm{C}$. The resulting supernatant was used for the analysis of esterases and proteins.

\subsubsection{Enzyme Assay}

Esterase activity using $\alpha$-naphthylacetate (a stock solution of $0.03 \mathrm{M} \alpha$-naphthyl acetate in acetone was prepared and diluted 100 times in $0.033 \mathrm{M}$ phosphate buffer, $\mathrm{pH}$ 7.0, just before assay) as a substrate was determined [5] [6] $1.0 \mathrm{ml}$ of suitably diluted enzyme extract was added to $5.0 \mathrm{ml}$ of the substrate and incubated for exactly 15 mins at $25^{\circ} \mathrm{C}$. The reaction is stopped by the addition of $1.0 \mathrm{ml}$ of DBLS reagent (5\% SDS and $1 \%$ diazo blue B mixed in the ratio $5: 2$, just before use). One unit of enzyme activity is defined as the amount of enzyme that releases one $\mu \mathrm{mol}$ of $\alpha$-naphthol per min at $\mathrm{pH} 7.0$ and $25^{\circ} \mathrm{C}$.

\subsubsection{Protein Estimation}

Protein was quantitatively estimated using bovine serum albumin (BSA) as standard [7].

\subsection{Kinetic Parameters}

\subsubsection{Effect of Time}

Effect of time on the crude enzyme extract (15 day endosperm extract) from the seeds of tamarind is carried out by incubating with $\alpha$-naphthyl acetate for different time intervals and assayed as described above.

\subsubsection{Effect of Substrate Concentration}

The endosperm extract is assayed for esterase by incubating with different concentration of the substrate, $\alpha$-naphthyl acetate for 15 mins as described above. Km and Vmax for esterase is determined by construction of LB-plot. 


\subsection{3. pH Optima}

The endosperm extract is assayed, using $\alpha$-naphthyl acetate in $50 \mathrm{mM}$ buffers of different $\mathrm{pH}$ (acetate buffer $\mathrm{pH}$ 4.0, 4.5, 5.0 and 5.5, phosphate buffer $\mathrm{pH}$ 6.0, 6.5, 7.0 and 7.5, Tris-HCl buffer $\mathrm{pH}$ 8.0, 8.5 and 9.0 and carbonate buffer $\mathrm{pH}$ 9.5, 10.0, 10.5 and 11.0) as described above.

\subsection{4. pH Stability}

The endosperm extract is pre-incubated with $50 \mathrm{mM}$ buffers of different $\mathrm{pH}$ (acetate buffer $\mathrm{pH}$ 4.0, 4.5, 5.0 and 5.5, phosphate buffer $\mathrm{pH}$ 6.0, 6.5, 7.0 and 7.5, Tris-HCl buffer $\mathrm{pH}$ 8.0, 8.5 and 9.0, carbonate buffer $\mathrm{pH} 9.5,10.0$, 10.5 and 11.0) for $2 \mathrm{hrs}$ at $4^{\circ} \mathrm{C}$. A known aliquots from the pre-incubated samples were removed and assayed as described above at an optimum $\mathrm{pH}$ of 7.0.

\subsubsection{Temperature Optima}

The optimum temperature is determined by assaying the endosperm extract at different temperatures, such as, $5^{\circ} \mathrm{C}, 10^{\circ} \mathrm{C}, 17^{\circ} \mathrm{C}, 22^{\circ} \mathrm{C}, 27^{\circ} \mathrm{C}, 32^{\circ} \mathrm{C}, 37^{\circ} \mathrm{C}, 42^{\circ} \mathrm{C}, 47^{\circ} \mathrm{C}, 52^{\circ} \mathrm{C}, 60^{\circ} \mathrm{C}, 70^{\circ} \mathrm{C}$ and $80^{\circ} \mathrm{C}$ using $\alpha$-naphthyl acetate as the substrate, for 15 mins.

\subsubsection{Temperature Stability}

The endosperm extract is pre-incubated at different temperatures, such as, $5^{\circ} \mathrm{C}, 10^{\circ} \mathrm{C}, 17^{\circ} \mathrm{C}, 22^{\circ} \mathrm{C}, 27^{\circ} \mathrm{C}, 32^{\circ} \mathrm{C}$, $37^{\circ} \mathrm{C}, 42^{\circ} \mathrm{C}, 47^{\circ} \mathrm{C}, 52^{\circ} \mathrm{C}, 60^{\circ} \mathrm{C}, 70^{\circ} \mathrm{C}$ and $80^{\circ} \mathrm{C}$ for 30 mins, rapidly cooled to $0^{\circ} \mathrm{C}$ and assayed using $\alpha$-naphthyl acetate at $25^{\circ} \mathrm{C}$, as described above.

\subsubsection{Polyacrylamide Gel Electrophoresis (PAGE)}

Polyacrylamide gel electrophoresis (PAGE) was performed essentially [8] [9] at $\mathrm{pH}$ 8.9. A discontinuous vertical slab gel system $(8 \mathrm{~cm} \times 8 \mathrm{~cm})$ containing $10 \%$ separating gel and $4.5 \%$ spacer gel was used. An aliquot of the enzyme extract suitably diluted with $40 \%$ glycerol solution containing bromophenol blue was carefully layered into the wells and subjected to electrophoresis for $2 \mathrm{hrs}$ at $10^{\circ} \mathrm{C}$ maintaining a current of $20 \mathrm{~mA}$.

\subsubsection{Staining for Esterase Activity}

Esterase activities on polyacrylamide gels are detected by the method of Hunter and Markert [10]. The electrophoresed gels were placed in $100 \mathrm{ml}$ of 0.1 M sodium phosphate buffer, $\mathrm{pH}$ 7.0, containing $40 \mathrm{mg}$ Fast Blue RR salt and $20 \mathrm{mg} \alpha$-naphthyl acetate in $1 \mathrm{ml}$ acetone, for 15 minutes at $37^{\circ} \mathrm{C}$. The gels are stored in $7 \%$ acetic acid.

\subsubsection{Inhibition Studies}

Inhibition studies are carried out employing colorimetric method. Suitably diluted enzyme extract $(0.5 \mathrm{ml})$ is pre-incubated with $0.5 \mathrm{ml}$ of different concentrations $\left(1 \times 10^{-3}\right.$ to $\left.1 \times 10^{-10} \mathrm{M}\right)$ of organophosphate (dicholrvos), carbamates (eserine sulphate) and sulphydryl (PCMB) inhibitors for 30 mins at $27^{\circ} \mathrm{C}$. The residual esterase activity is then assayed using $5.0 \mathrm{ml}$ of $\alpha$-naphthyl acetate as described above.

\subsubsection{Inhibition Studies Employing PAGE}

The effect of different inhibitors (dichlorvos, eserine sulphate and PCMB) on the esterases separated after electrophoresis is studied by pre-incubating the gels in different inhibitor solutions $\left(1 \times 10^{-5} \mathrm{M}\right)$ for 30 mins, followed by thorough washing of the gels with $0.05 \mathrm{M}$ phosphate buffer, $\mathrm{pH} 7.0$ and staining for esterase activity as described above.

\section{Result}

Preliminary experiments are carried out to determine the standard conditions for the assay of esterases from the tamarind seed extract. The esterase activity of the crude enzyme extract is linear up to $50 \mu \mathrm{g}$ protein (Figure 1) and 50 mins (Figure 2). $\mathrm{Km}$ is a measure of the affinity of an enzyme for a particular substrate. The Km value of esterase extract with $\alpha$-naphthyl acetate as substrate is found be $19.23 \mu \mathrm{M}$ (Figure 3 and Figure 4). The pH optima of plant esterases usually lie in the range of 4 to 9 . The $\mathrm{pH}$ optima of tamarind seed esterase is 7.0 to 7.5 (Figure 5) and is stable between $\mathrm{pH} 5.0$ to 9.0 (Figure 6). The optimum temperature of esterase activity of tamarind seed is between $37^{\circ} \mathrm{C}-50^{\circ} \mathrm{C}$ (Figure 7) and is stable up to $40^{\circ} \mathrm{C}$. The activity declined by $30 \%$ at $60^{\circ} \mathrm{C}$ and about $90 \%$ at $70^{\circ} \mathrm{C}$ (Figure 8). 


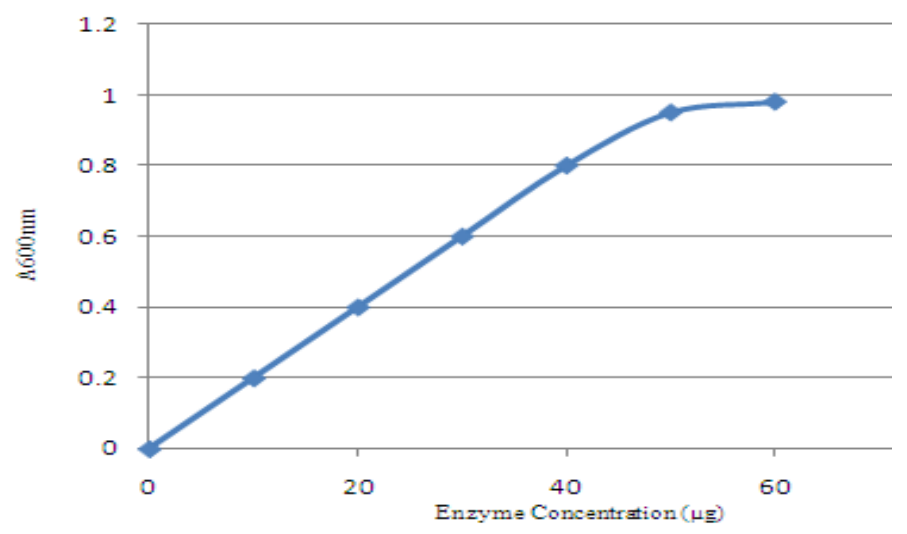

Figure 1. Effect of protein concentration on esterase activity.

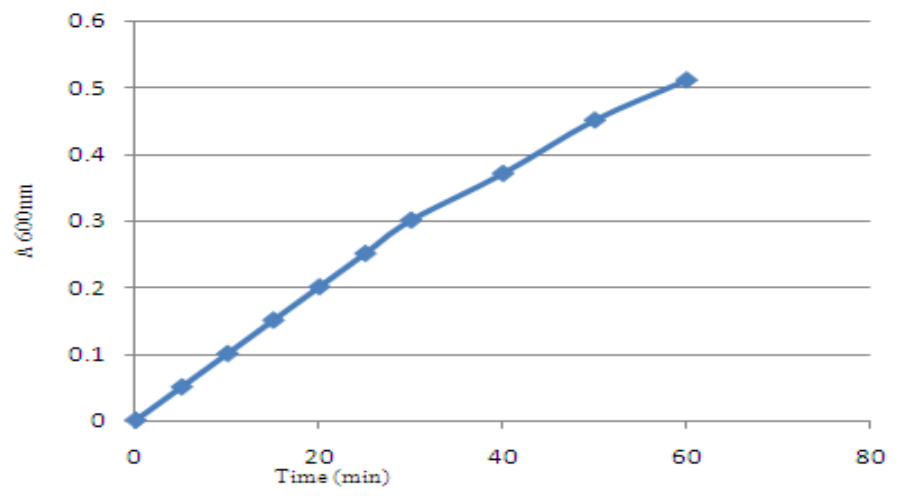

Figure 2. Time curve for esterase.

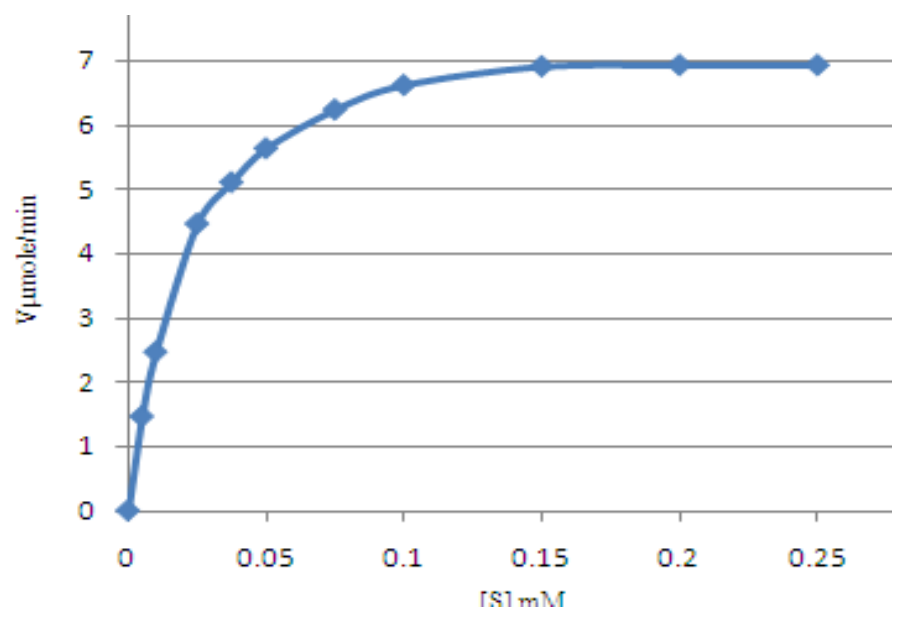

Figure 3. Effect of substrate concentration on esterase activity.

The tamarind seeds are germinated for 25 days and the changes in total esterase activity, specific activity and protein are followed every alternate day (Figure 9). Analysis of the total esterase activity pattern during germination of the endosperm showed highest activity on $5^{\text {th }}$ day, $11^{\text {th }}$ to $15^{\text {th }}$ day and $21^{\text {st }}$ day of germination and lowest activity on $7^{\text {th }}$ and $9^{\text {th }}$ day and $17^{\text {th }}$ and $19^{\text {th }}$ day. They exhibited a constant cyclic increase and decrease of total activity during the germination period. The specific activity was maximum on $21^{\text {st }}$ day of germination and exhibited a cyclic increase and decrease of specific activity during the germination period similar to total activity. However, the specific activity constantly increased during the whole germination period reaching a maxi- 


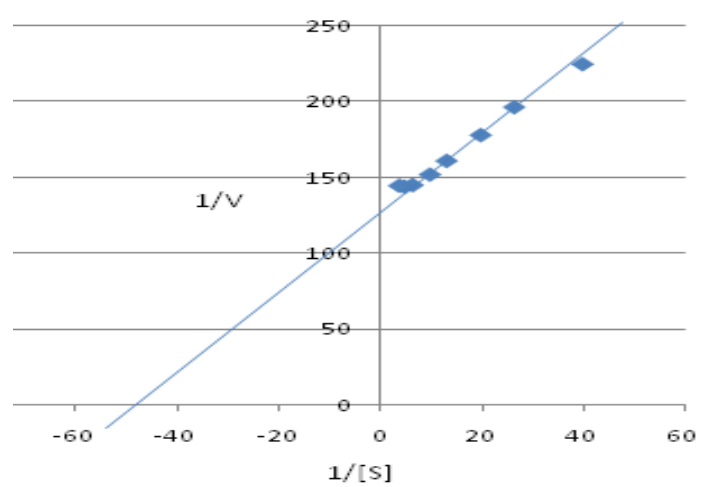

Figure 4. $\mathrm{K}_{\mathrm{m}} \& \mathrm{~V}_{\max }$ of esterase.

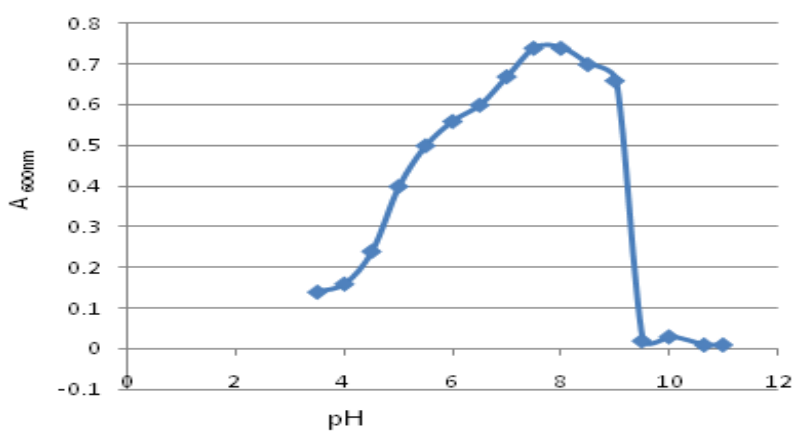

Figure 5. Effect of $\mathrm{pH}$ on esterase activity.

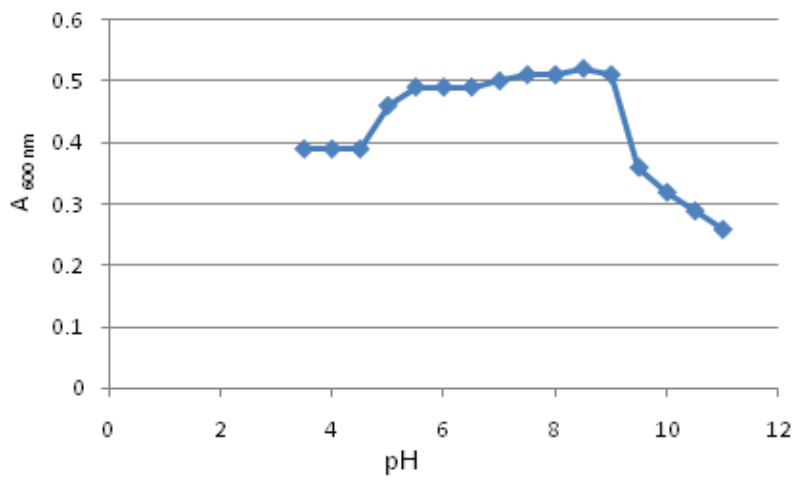

Figure 6. pH stability of esterase.

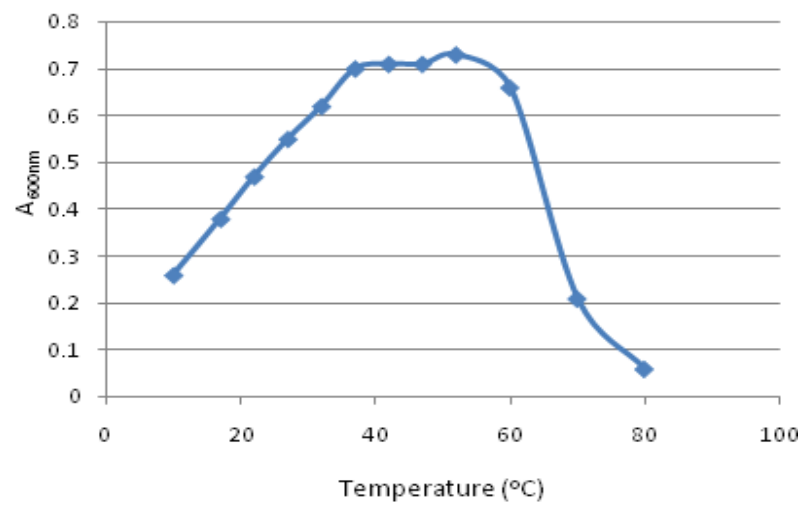

Figure 7. Effect of temperature on esterase activity. 


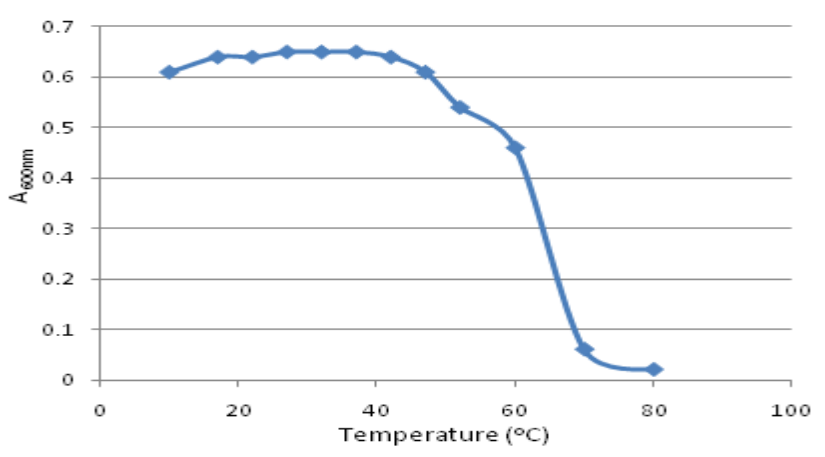

Figure 8. Temperature stability of esterase.

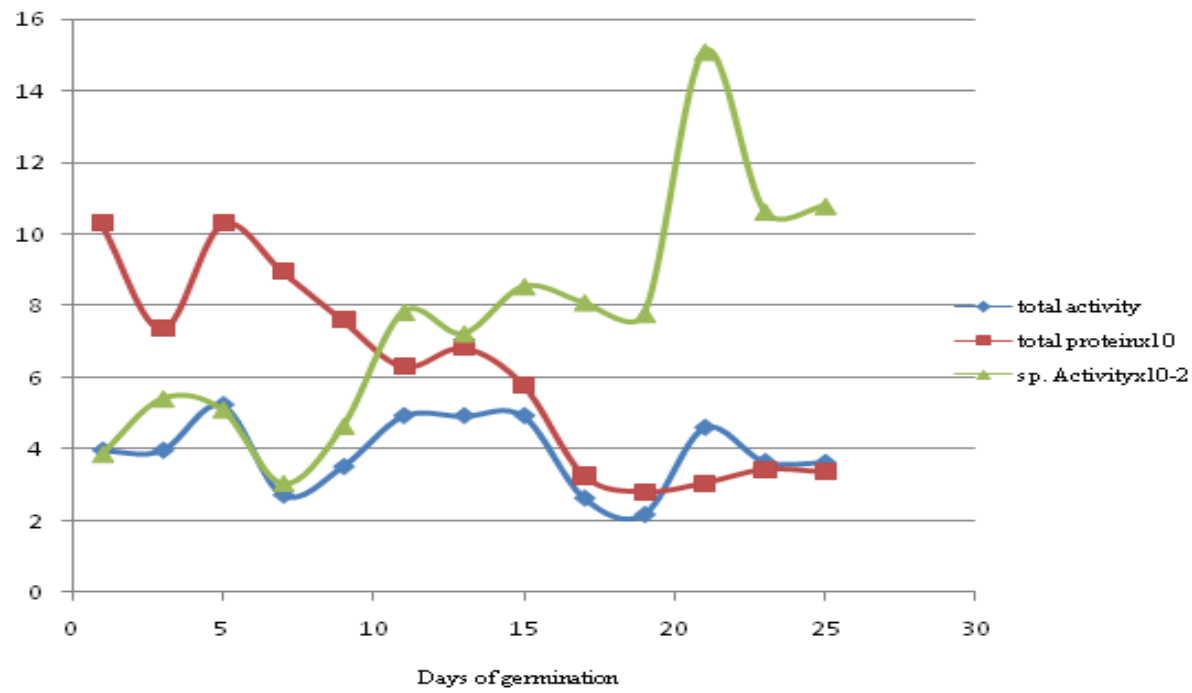

Figure 9. Germination profile of esterase.

mum on $21^{\text {st }}$ day. The total protein of the endosperm is maximum on $1^{\text {st }}$ and $5^{\text {th }}$ day of germination and exhibited a cyclic increase and decrease during the germination period similar to total esterase activity. However, in contrast to the specific activity which continuously increased during the germination period, the protein continuously decreased during the germination period reaching a minimum on $19^{\text {th }}$ day. The effect of continuous decrease in protein and a constant increase and decrease in total esterase activity resulted in a continuous increase in specific activity during the germination period.

Electrophoretic analysis of the esterase activity during the germination from $1^{\text {st }}$ to $25^{\text {th }}$ day is shown in Figure 10. Totally nine isozymes were separated by PAGE. The bands were numbered consecutively from the anodic end of the gel. Band number 1, 4, 5, 6 and 9 are present on all the days while band numbers $2 \& 3$ were minor bands present only during the latter period of the germination. Band numbers 1, 5 and 6 were the major esterolytic bands present throughout the germination period.

Highest esterase activity and specific activity and very low protein content were present in the endosperms on $21^{\text {st }}$ day of germination. Hence, 21-day-old germinated endosperms were used to characterize the esterases. The plots of pI (inhibitor concentration) versus percent inhibition of the esterases with dichlorvos, PCMB and esirene sulphate is presented in Figure 11. Single sigmoidal curves are obtained with both the organophosphate and PCMB, while eserine sulphate did not affect the activity of esterases. Dichlorvos completely inhibited the esterases activity at PI 5, while with PCMB only 50\% activity is inhibited. The $\mathrm{I}_{50}$ of dichlorvos and PCMB are in the range of pI 6 to 7 and pI 5, respectively.

The results of inhibition studies in conjunction with electrophoresis are shown in Figure 12. The esterolytic bands 1 to 8 are completely inhibited by OP inhibitor PCMBs, while band 9 is inhibited only by OP inhibitor. However, all the bands are resistant to carbamate inhibitor, eserine sulphate. 


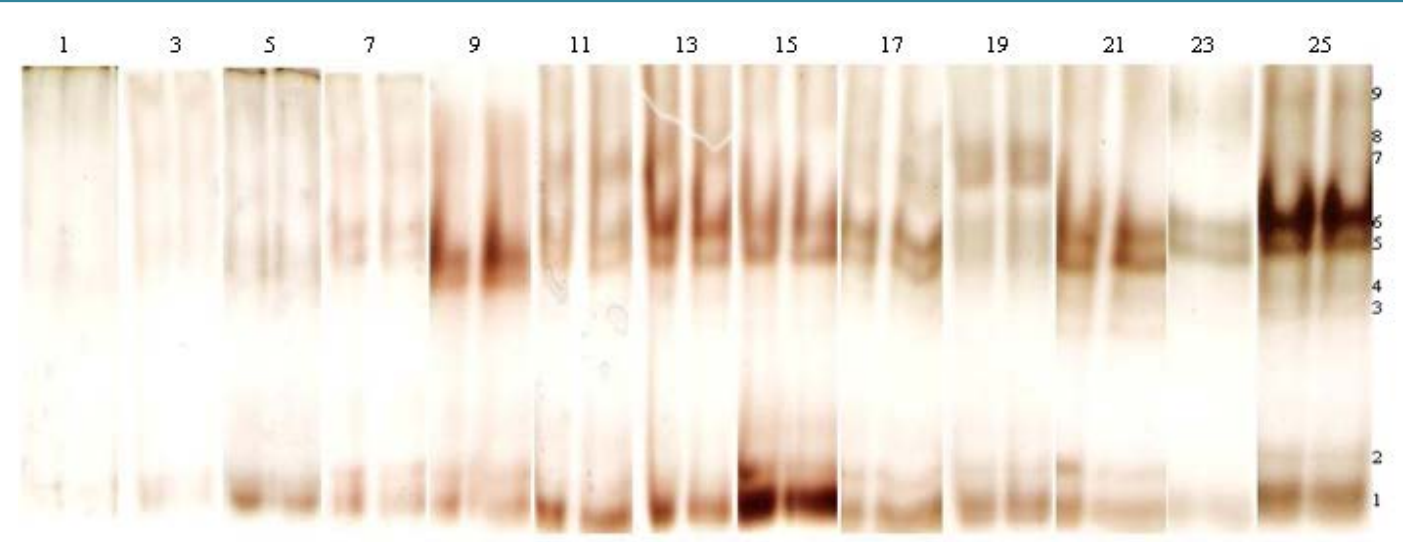

Figure 10. Electrophoretic pattern of esterase during germination of tamarind seeds.

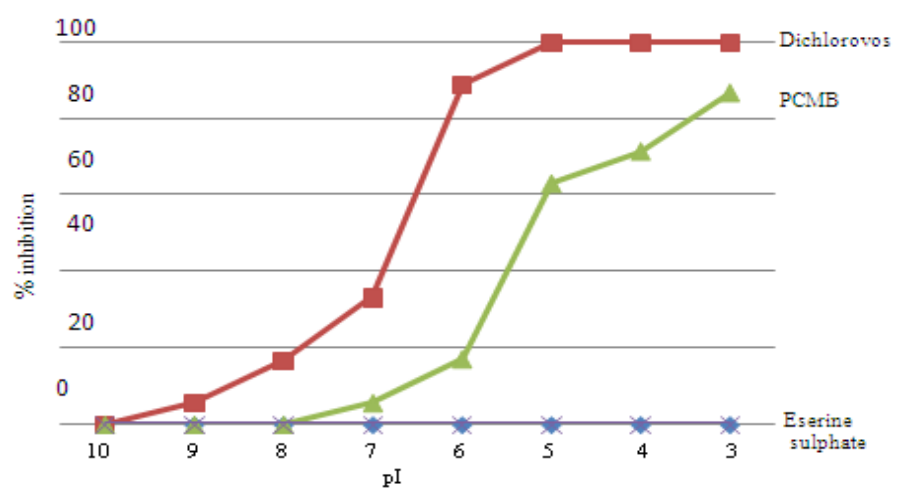

Figure 11. Effect of Inhibitors on esterase activity.

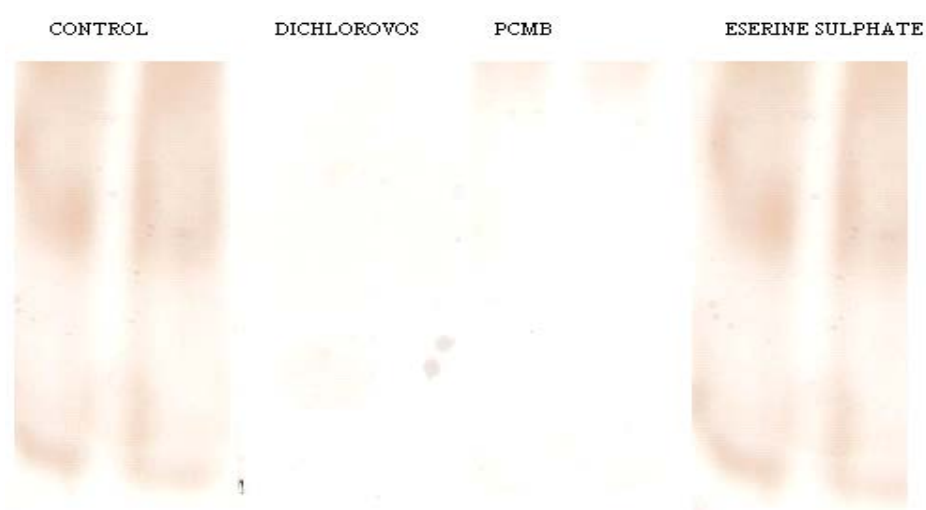

Figure 12. PAGE of effect of Inhibitors on esterase activity.

\section{Discussion}

The esterases have been extracted from plants using various buffer systems and phosphate buffer, $\mathrm{pH}$ 7, is found to be ideal for the extraction [11]. During the germination of seeds, there is continuous synthesis and/or degradation of specific enzymes and structural proteins. The appearance of new or increased enzyme activity results from either the de novo synthesis of the enzyme molecule or the activation of a pre-existing enzyme precursor.

Non-specific esterases represent a large, diverse and complex group of major hydrolytic enzymes and posses the property of overlapping substrate specificity, hydrolysing both endogenous and exogenous esters of widely differing structures leading to problems of identification and classification [12] [13]. Generally esterases have been classified into three types based on their interactions with inhibitors [14]. Carboxylesterases are inhibited 
by OP while cholinesterases are inhibited by both OP and carbamate inhibitors. However, arylesterases are not inhibited by OP but hydrolyze OP while acetylesterases are not inhibited by OP or do not hydrolyze OP.

A subsequent elaboration of the Aldridge and Reiner [14] scheme has been used to classify esterase isozymes detected after native PAGE and stained with various artificial ester substrates, in conjunction with organophosphate (OP), sulfhydryl, and the carbamate inhibitors [15]-[17]. Based on the above studies, the esterases from the tamarind seeds have been classified as carboxylesterases and carboxylesterases sensitive to sulphydryl inhibitors. Similarly on the basis of above criteria, two purified Mucuna pruriens seed esterases (MEIII and ME-IV) separated by PAGE were stained with 1-naphthyl acetate in conjunction with OPs, carbamates and sulphydryl inhibitors and the esterases were classified as carboxylesterases. Similar observations were noticed in case of insect carboxylesterases [18] [19].

\section{Acknowledgements}

We acknowledge University Grant Commission, New Delhi, for providing Fellowship and DOS in Biochemistry, Bangalore University, Bangalore for offering facilities to carry out the research work.

\section{References}

[1] Jung, Y.J., Lee, J.K., Sung, C.G., Oh, T.K. and Kima, H.K. (2003) Nonionic Detergent Induced Activation of an Esterase from Bacillus megaterium 20-1. Journal of Molecular Catalysis B: Enzymatic, 26, 223-229. http://dx.doi.org/10.1016/j.molcatb.2003.06.006

[2] Potter, P.M. and Wadkins, R.M. (2006) Carboxylesterases: Detoxifying Enzymes and Targets for Drug Therapy. Current Medicinal Chemistry, 13, 1045-1054. http://dx.doi.org/10.2174/092986706776360969

[3] Abernathy, C.O. and Casida, J.E. (1973) Pyrethroid Insecticides: Esterase Cleavage in Relation to Selective Toxicity. Science, 179, 1235-1236. http://dx.doi.org/10.1126/science.179.4079.1235

[4] Wheelock, C.E., Miller, J.L., Miller, M.G., Shan, G., Gee, S.J. and Hammock, B.D. (2004) Development of Toxicity Identification Evaluation (TIE) Procedures for Pyrethroid Detection Using Esterase Activity. Environmental Toxicology and Chemistry, 23, 2699-2708. http://dx.doi.org/10.1897/03-544

[5] Gomori, G. (1953) Human Esterases. Journal of Laboratory and Clinical Medicine, 42, 445-453.

[6] Van Asperen, K. (1962) A Study of House Fly Esterase by Means of a Sensitive Colorimetric Method. Journal of Insect Physiology, 8, 401-416. http://dx.doi.org/10.1016/0022-1910(62)90074-4

[7] Lowry, O.H., Rosebrough, N.J., Farr, A.L. and Randall, R.J. (1951) Protein Measurements with the Folin Phenol Reagent. Journal of Biological Chemistry, 193, 265-275.

[8] Davis, B.J. (1964) Disc Electrophoresis-II Method and Application to Human Serum Proteins. Annals of the New York Academy of Sciences, 121, 404-427. http://dx.doi.org/10.1111/j.1749-6632.1964.tb14213.x

[9] Ornstein, L. (1964) Disc Electrophoresis. I. Background and Theory. Annals of the New York Academy of Sciences, 121, 321-349. http://dx.doi.org/10.1111/j.1749-6632.1964.tb14207.x

[10] Hunter, R.L. and Markert, C.L. (1957) Histochemical Demonstration of Isozymes Separated by Zone Electrophoresis in Starch Gels. Science, 125, 1294-1295. http://dx.doi.org/10.1126/science.125.3261.1294-a

[11] Subramani, T., Manjunath, K.C., Siddalinga Murthy, K.R. and Ramachandra Swamy, N. (2012) Esterase Activity from the Germinated Jatropha curcas Seeds in Different Extraction Buffers. International Journal of Science and Nature (IJSN), 3, 170-172.

[12] Dixon, M. and Webb, E.C. (1979) In Enzymes. Academic Press, London, 207-215.

[13] Walker, C.H. and Mackness, M.I. (1983) Esterases: Problems of Identification and Classification. Biochemical Pharmacology, 32, 3265-3326. http://dx.doi.org/10.1016/0006-2952(83)90349-0

[14] Aldridge, W.N. and Reiner, E. (1972) In Enzyme Inhibitors as Substrates. North Holland, Amsterdam.

[15] Holmes, R.S. and Masters, C.J. (1967) The Developmental Multiplicity and Isoenzyme Status of Cavian Esterases. Biochimica et Biophysica Acta, 132, 379-399. http://dx.doi.org/10.1016/0005-2744(67)90157-X

[16] Coates, P.M., Mestriner, M.A. and Hopkinson, D.A. (1975) A Preliminary Genetic Interpretation of the Esterase Isozymes of Human Tissues. Annals of Human Genetics, 39,1-20. http://dx.doi.org/10.1111/j.1469-1809.1975.tb00103.x

[17] Healy, M.J., Dumancic, M.M. and Oakeshott, J.G. (1991) Biochemical and Physisological Studies of Soluble Esterases from Drosophila melanogaster. Biochemical Genetics, 29, 365-388. http://dx.doi.org/10.1007/BF00554144

[18] Sreerama, L. and Veerabhadrappa, P.S. (1991) Purification and Properties of Carboxylesterases from the Midgut of the Termite Odentotermes horni. Insect Biochemistry, 21, 833-844. http://dx.doi.org/10.1016/0020-1790(91)90090-2 
[19] Siddalinga Murthy, K.R. and Veerabhadrappa, P.S. (1996) Purification, Characterization and Properties of Carboxylesterase from the Midgut of the Silkworm, Bombyx mori L. Insect Biochemistry and Molecular Biology, 26, 287-296. http://dx.doi.org/10.1016/0965-1748(95)00091-7 